\title{
A Five-Year Radar-Based Climatology of Tropopause Folds and Deep Convection over Wales, United Kingdom
}

\author{
Bogdan Antonescu, Geraint Vaughan, And David M. Schultz \\ Centre for Atmospheric Science, School of Earth, Atmospheric and Environmental Science, \\ University of Manchester, Manchester, United Kingdom
}

(Manuscript received 16 August 2012, in final form 22 October 2012)

\begin{abstract}
A five-year (2006-10) radar-based climatology of tropopause folds and convective storms was constructed for Wales, United Kingdom, to determine how deep, moist convection is modulated by tropopause folds. Based on the continuous, high-resolution data from a very high frequency (VHF) wind-profiling radar located at Capel Dewi, Wales, 183 tropopause folds were identified. Tropopause folds were most frequent in January with a secondary maximum in July. Based on data from the U.K. weather radar network, a climatology of 685 convective storms was developed. The occurrence of convective storms was relatively high year-round except for an abrupt minimum in February-April. Multicellular lines (43.5\%) were the most common morphology with a maximum in October, followed by isolated cells $(33.1 \%)$ with a maximum in May-September, and nonlinear clusters $(23.4 \%)$ with a maximum in November-January. Convective storms were associated with $104(56.8 \%)$ of the tropopause folds identified in this study, with the association strongest in December. Of the 55 tropopause folds observed on the eastern side of an upper-level trough, 37 (67.3\%) were associated with convective storms, most commonly in the form of multicellular lines. Of the 128 tropopause folds observed on the western side of an upper-level trough, $42(32.8 \%)$ were associated with convective storms, most commonly isolated cells. These results suggest that more organized storms tend to form in environments favorable for synoptic-scale ascent.
\end{abstract}

\section{Introduction}

Tropopause folds, or extrusions of stratospheric air into the troposphere, form in the upper-level frontal zones beneath the polar and subtropical jet streams. Occurring in breaking Rossby waves, tropopause folds can drive stratospheric air deep into the troposphere (Danielsen 1968). As well as elevated ozone and reduced humidity, stratospheric air possesses high potential vorticity, a property that means tropopause folds influence the dynamics of the troposphere. Since the first documented studies of tropopause folding events (Reed and Sanders 1953; Newton 1954; Reed 1955), reports of their meteorological effects have fallen into three main classes: the intensification of cyclones (e.g., Uccellini et al. 1985; Uccellini 1990; Wernli et al. 2002), damaging

Corresponding author address: Dr. Bogdan Antonescu, Centre for Atmospheric Science, School of Earth, Atmospheric and Environmental Science, University of Manchester, Simon Building, Oxford Road, Manchester, M13 9PL, United Kingdom.

E-mail: bogdan.antonescu@manchester.ac.uk surface winds (e.g., Browning and Reynolds 1994; Pauley et al. 1996), and the promotion or suppression of convection (e.g., Browning and Roberts 1994; Thorpe 1997; Griffiths et al. 2000; Goering et al. 2001). This study focuses on tropopause folds and convective storms.

Deep, moist convection requires three basic ingredients: moisture, instability, and lift (Johns and Doswell 1992). If sufficient moisture and conditional instability are already present, an important forecast issue is whether the lift is sufficient to overcome convective inhibition (Doswell and Bosart 2001). If all the ingredients are present, the next step is to forecast the resulting location, intensity, and morphology of convective storms. Despite the rapid development of numerical weather prediction models and implementation of new observational techniques, the location, intensity, and morphology of deep, moist convection remains a challenge for operational weather forecasting. One possible hypothesis that may lead to better forecasting of deep convection is the role played by tropopause folds.

When analyzed from the perspective of the ingredientbased methodology, tropopause folds can affect all three 
ingredients in a way that can either promote or suppress convective storms. First, the entrainment of dry air associated with tropopause folds can suppress convective storms through negative buoyancy produced by cooling due to evaporation. Second, the static stability of recently formed tropopause folds is characteristic of the stratosphere, leading to convective inhibition (Danielsen 1968). Third, lift is favored by the advection of potential vorticity (PV) associated with tropopause folds (Hoskins et al. 1985). Such ascent can reduce convective inhibition and promote the development of deep convection (Doswell and Bosart 2001; Markowski and Richardson 2010, p. 184). In addition, two further characteristics of the environment where tropopause folds are found can increase instability. (i) A low tropopause brings cold air aloft and augments conditional instability (Hoskins et al. 1985); for example, Gold and Nielsen-Gammon (2008) used nonlinear balance PV inversion to diagnose the sensitivity of convective indices to the amplitude of a subsynoptic-scale PV anomaly and found that stronger anomalies increase the convective available potential energy (CAPE) due to the cooling of the temperature profile in the mid- and upper troposphere. (ii) Recently descended, dry, upper-tropospheric air can overrun warm moist air in the boundary layer, creating potential instability (Danielsen 1968; Roberts 2000); for example, Browning and Roberts (1994) showed thunderstorms breaking out on the leading edge of an overrunning dry layer. Thus, a series of questions can be raised regarding the interaction between tropopause folds and convective storms in particular, how is deep convection modulated by tropopause folds, and how does the structure of tropopause folds affect the location, intensity, and morphology of the resulting convection? This article proposes an initial investigation to explore these questions.

The goal of this article is to develop a climatology of tropopause folds and convective storms. This climatology will provide the basis for subsequent studies that will analyze the physical mechanisms linking tropopause folds and convective storms. To accomplish this goal, data with high temporal availability from the U.K. Natural Environment Research Council (NERC) mesospherestratosphere-troposphere (MST) radar (Vaughan 2002) and weather radar data from the U.K. Meteorological Office (Met Office) from 2006-10 were used to develop a climatology of convective storms associated with tropopause folds for Wales, United Kingdom.

This article is structured as follows. Section 2a details the data and approach used to identify tropopause folds. Section $2 b$ describes the climatology of tropopause folds over Wales. Section 3a documents the weather-radar data used in this study, and section $3 \mathrm{~b}$ describes the approach to identify convective storms. The radar-based climatology of convective storms over Wales is presented in section 3c. Section 4a details how convective storms are attributed to tropopause folds. The climatology of tropopause folds associated with convective storms is presented in section $4 \mathrm{~b}$. Section 5 discusses the relationship between convective storms and synopticscale forcing, drawing from previously published papers and current conceptual models. Finally, section 6 summarizes the results of this paper.

\section{Tropopause folds}

\section{a. Previous methods for detecting tropopause folds}

Various algorithms have been proposed to detect tropopause folds. Because the stratospheric air in a fold is characterized by high values of ozone mixing ratio, high PV, and low relative humidity, these algorithms use vertical profiles of ozone, temperature, or humidity measured in situ (e.g., Van Haver et al. 1996; Beekmann et al. 1997) or diagnostic quantities (e.g., PV, Q-vector) derived from meteorological analyses (e.g., Elbern et al. 1998; Sprenger et al. 2003).

The advantage of using in situ profiles is the vertical resolution of the data, which allows tropopause folds to be identified by applying certain threshold values to the measured quantities. For example, Van Haver et al. (1996) identified tropopause folds as layers in which the following criteria are met: (i) the ozone mixing ratio is at least $25 \%$ larger than the climatological mean, (ii) the relative humidity is less than $25 \%$, and (iii) the vertical gradient of potential temperature is greater than $11.5 \mathrm{~K}$ $(100 \mathrm{hPa})^{-1}$. These criteria can also identify detached layers of stratospheric air well away from the jet stream as tropopause folds. To eliminate such cases, Van Haver et al. (1996) added two additional criteria: the layers must be observed within a frontal zone (vertical gradient of the wind speed $>5 \mathrm{~m} \mathrm{~s}^{-1} \mathrm{~km}^{-1}$ ) and must be near an upper-tropospheric jet stream (wind speed $>20 \mathrm{~m} \mathrm{~s}^{-1}$ ). Adding criteria or refining the threshold values allows unambiguous identification of tropopause folds, but the disadvantage of algorithms using ozonesonde profiles is the sparse location and infrequent measurements of ozone sounding stations.

A solution to this problem is offered by the second category of algorithms, those based on global meteorological analyses. For example, Elbern et al. (1998) developed a tropopause-fold detection algorithm based on T63 European Centre for Medium-Range Weather Forecasts (ECMWF) analyses. Because these analyses were too coarse to resolve tropopause folds, the algorithm looked for a joint occurrence of a PV maximum and 


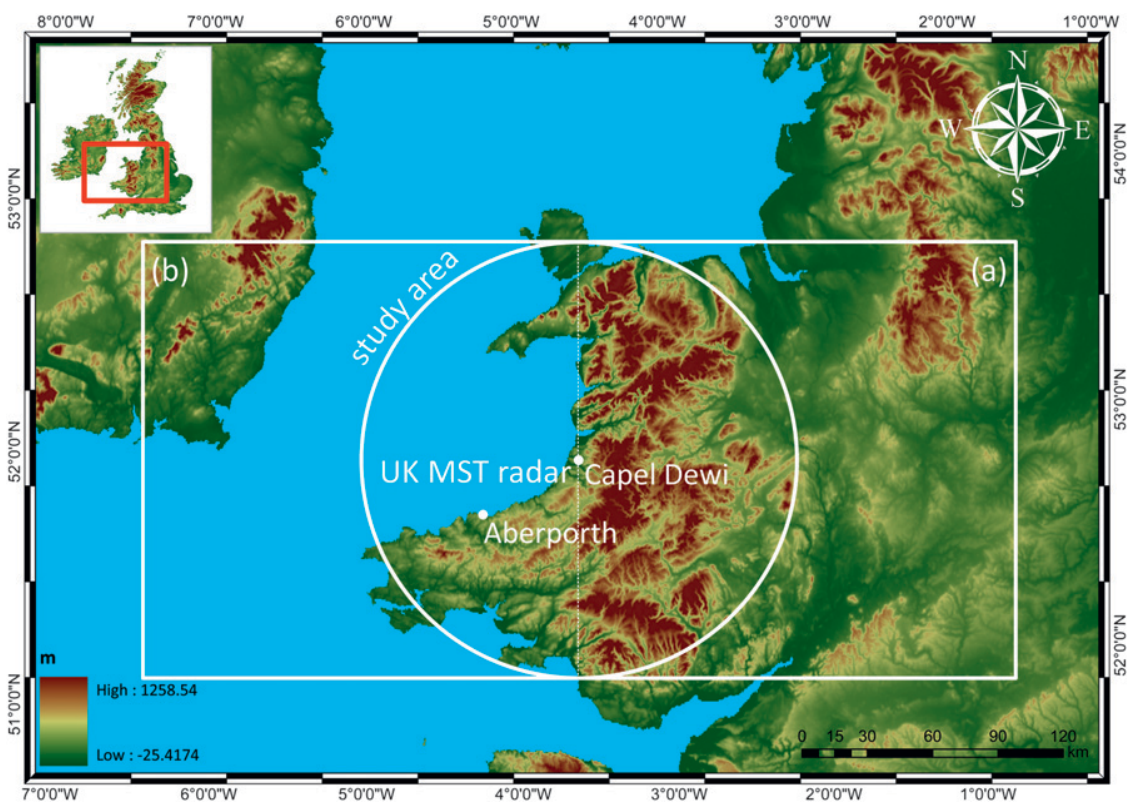

FIG. 1. Location of the study area defined as a circle with radius $100-\mathrm{km}$ around the mesosphere-stratosphere-troposphere (MST) radar at Capel Dewi $\left(52.42^{\circ} \mathrm{N}, 4.01^{\circ} \mathrm{W}\right)$ near Aberystwyth, Wales. The rectangles $(200 \mathrm{~km} \times 200 \mathrm{~km})$ indicate the (a) downwind and (b) upwind study areas from the MST radar. Aberporth is a radiosonde launching site used as a proximity sounding for the study area.

a Q-vector (Hoskins et al. 1978) divergence maximum between 500 and $400 \mathrm{hPa}$, corresponding to frontogenetically induced subsidence.

As higher-resolution analyses became available, tropopause folds could be identified directly from model fields. For example, Sprenger et al. (2003) used ECMWF global analyses (T319L60 and T511L60) to develop a geometrical tropopause-fold definition. Their algorithm identified tropopause folds in pseudosoundings as areas of multiple crossings of the dynamic tropopause $[2$ potential vorticity units (PVU), where 1 PVU = $10^{-6} \mathrm{~m}^{2} \mathrm{~K} \mathrm{~s}^{-1} \mathrm{~kg}^{-1}$. Such algorithms can be used successfully to develop global climatologies of folding, but are less useful for studying the influence of tropopause folds on convection due to the low temporal resolution of meteorological analyses.

The limited vertical resolution of meteorological analyses, together with the limited temporal sampling, can be overcome by using data from a very high frequency (VHF) wind-profiling radar to detect tropopause folds (e.g., Vaughan et al. 1994; Vaughan and Worthington 2000; Reid and Vaughan 2004; Parton et al. 2010). Such radars typically offer a vertical gate spacing of 200-300 m and sample every $10 \mathrm{~min}$ or less.

In this article, we identify tropopause folds using data from the MST radar located at Capel Dewi $\left(52.42^{\circ} \mathrm{N}\right.$, $4.01^{\circ} \mathrm{W}$ ) near Aberystwyth in mid-Wales (Fig. 1). The three-dimensional wind field above the MST site is determined using the Doppler beam-swinging technique, whereby a combination of Doppler velocities are taken along the zenith and at $6^{\circ}$ off-zenith directions at four orthogonal azimuths. The beam-swinging cycle takes around 4 min to complete and provides two wind estimates per cycle between $2 \mathrm{~km}$ and around $16 \mathrm{~km}$ at $150-\mathrm{m}$ intervals, although the pulse length of $2 \mu \mathrm{s}$ corresponds to a vertical gate spacing of $300 \mathrm{~m}$ (Parton et al. 2010). A description of the U.K. MST radar is found in Vaughan (2002).

In a time-height cross section of MST radar data, a candidate for a tropopause fold is first identified from a sharp change in the height of the tropopause (Nastrom et al. 1989), estimated as the height where the vertical gradient of echo power has its maximum value (Hooper and Arvelius 2000). The radar echo power is a function of static stability and vertical humidity gradient, with the negative gradient in humidity at the tropopause reinforcing the increased static stability (Vaughan and Worthington 2000). To indicate the presence of a tropopause fold, the sharp change in height must be associated with a sloping layer of high echo power from the tropopause toward the middle and lower troposphere (Reid and Vaughan 2004). This sloping layer must also be characterized by a maximum in the wind shear ( $>25 \mathrm{~m} \mathrm{~s}^{-1} \mathrm{~km}^{-1}$; Lawson et al. 2011). In addition, the wind speed in the tropopause region must be greater than $25 \mathrm{~m} \mathrm{~s}^{-1}$, thus ensuring the presence of an upper-level 


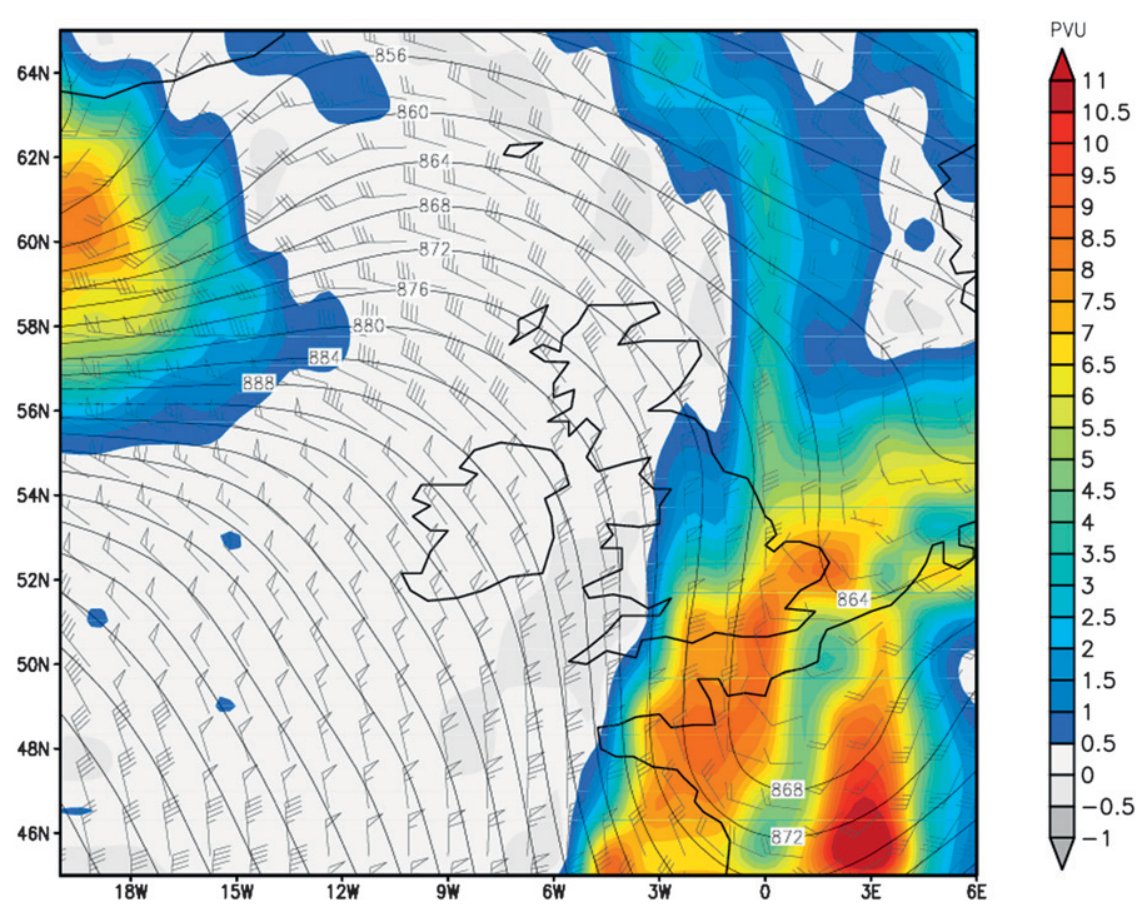

FIG. 2. ECMWF analysis of 300-hPa geopotential height (solid contours, 10-dam increment), winds (one pennant, full barb, and half-barb denote 25,5 , and $2.5 \mathrm{~m} \mathrm{~s}^{-1}$, respectively), and potential vorticity (shaded, 0.5-PVU increment) valid at 1200 UTC 7 Nov 2010.

jet stream (Glickman 2000, p. 426). This algorithm is similar to that applied by Rao et al. (2008) to data collected by the VHF radar at Esrange, Sweden.

As an example of the application of these criteria to tropopause-fold detection, we present a brief case study. During 7 November 2010, a 300-hPa geopotential height trough had passed eastward over the United Kingdom (Fig. 2). The trough appeared as an isolated region of stratospheric PV (>2 PVU) at $300 \mathrm{hPa}$. The tropopause fold on the western edge of the trough developed beneath a northerly jet, exceeding $25 \mathrm{~m} \mathrm{~s}^{-1}$.

The time-height cross sections of echo power $(\mathrm{dB})$, wind shear $\left(\mathrm{m} \mathrm{s}^{-1} \mathrm{~km}^{-1}\right)$, and wind speed $\left(\mathrm{m} \mathrm{s}^{-1}\right)$ from the MST radar are presented in Fig. 3. Because time runs from left to right, the western side of the tropopause fold lies on the right side of the figure. The following structures are observed:

(1a)-(1b) at 1000 UTC, a sharp increase of the tropopause height, as detected by the Hooper and Arvelius (2000) algorithm and identified by the plus signs (Fig. 3a);

(2a)-(2b) a sloping layer of high echo power descending from the tropopause toward the lower troposphere (Fig. 3a);

(3a)-(3b) the sloping layer of high echo power is also characterized by strong vertical wind shear (>30 $\mathrm{m} \mathrm{s}^{-1} \mathrm{~km}^{-1}$, Fig. 3b);
(4) the layer of strong vertical wind shear is observed beneath an upper-level jet stream $\left(>50 \mathrm{~m} \mathrm{~s}^{-1}\right.$, Fig. 3c).

Based on these structures, a tropopause fold can be identified in the MST data between 1000 and 1900 UTC. In fact, there are two lines of maximum shear in this cross section, with a weaker line of wind shear about $2 \mathrm{~km}$ below the main maximum, also corresponding to a maximum in echo power (Figs. 3a,b). This multibanded structure often occurs during tropopause-fold passages (Lawson et al. 2011) and may be understood by reference to an upwind radiosonde from Castor Bay at 0600 UTC, situated approximately $275 \mathrm{~km}$ north-northwest from the MST radar (Fig. 4). The fold is depicted here as the stability maximum around $500 \mathrm{hPa}$, coinciding with a humidity minimum and rotation of the wind with height. This fold is embedded in a deep dry layer, the base of which around $850 \mathrm{hPa}$ also coincides with rotation of the wind vector. The sharp change in humidity at the base of this layer results in the enhanced VHF echo power observed by the radar.

\section{b. Climatology}

In this study, 183 tropopause folds were identified in five years of data (2006-10), corresponding to an occurrence ratio (number of folds detected divided by the number of days studied) of $10.0 \%$. This agrees reasonably 
a) Echo Power (dB)

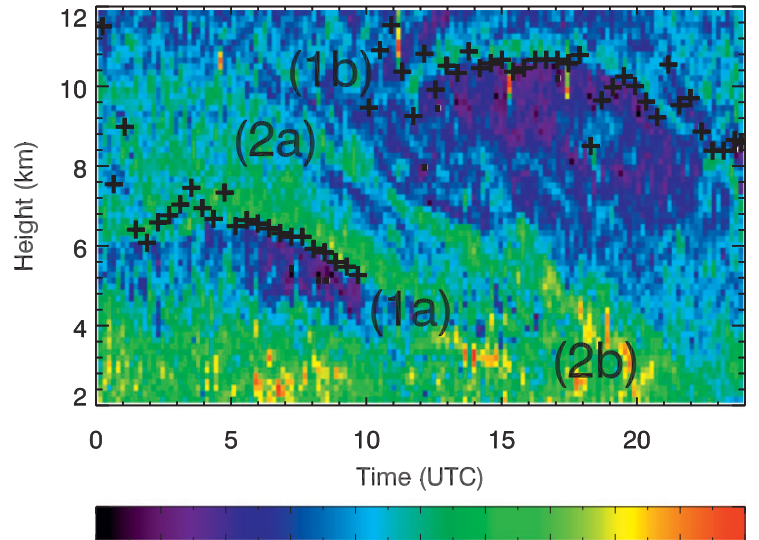

80. 86. 92. 98. 104. 110. 116. 122. 128. 134. 140.

b) Wind shear $\left(\mathrm{ms}^{-1} \mathrm{~km}^{-1}\right)$

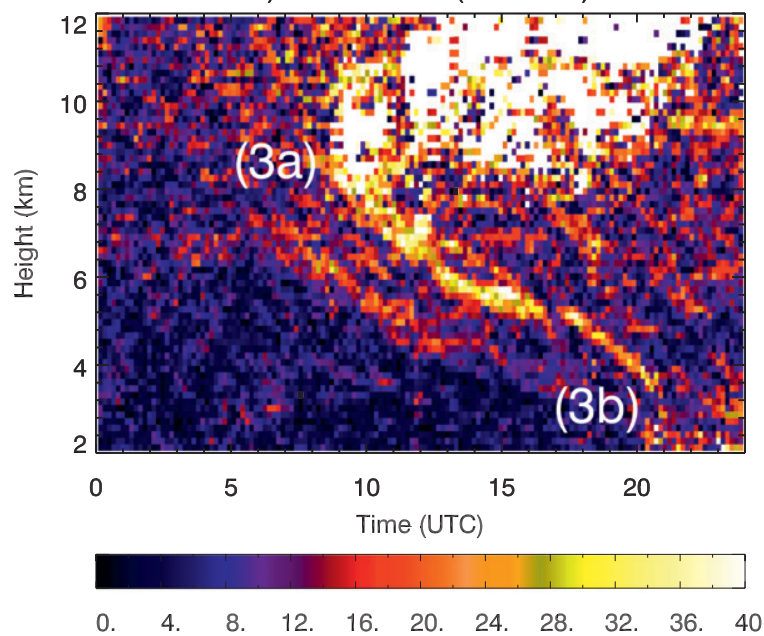

c) Wind speed $\left(\mathrm{ms}^{-1}\right)$

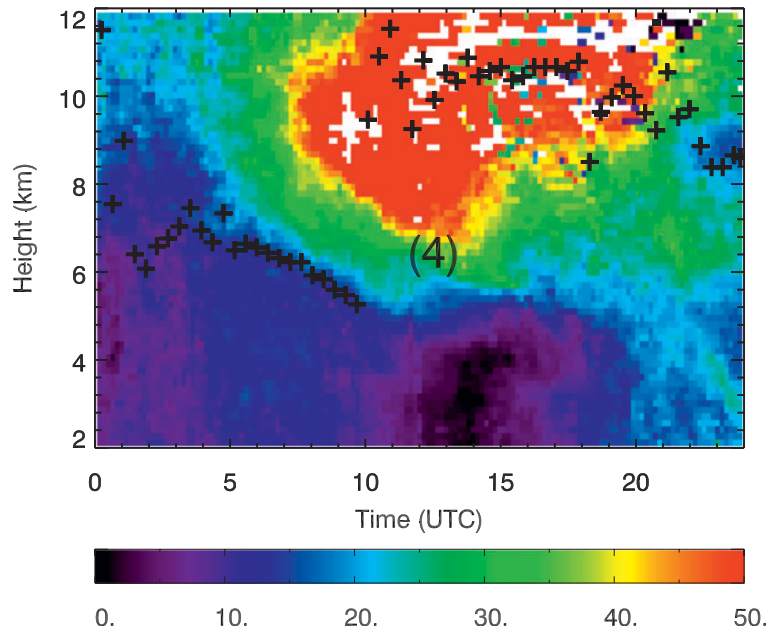

FIG. 3. Time-height cross sections for (a) echo power (dB), (b) vertical wind shear $\left(\mathrm{m} \mathrm{s}^{-1} \mathrm{~km}^{-1}\right)$, and (c) wind speed $\left(\mathrm{m} \mathrm{s}^{-1}\right)$ measured by the MST radar on 7 Nov 2010. The plus signs indicate the tropopause height as detected by the algorithm of Hooper and Arvelius (2000) well with the $7.4 \%$ occurrence ratio over Sweden found by Rao et al. (2008). The continuous measurements from MST radars mean that their occurrence ratios are larger than the values of $4.8 \%$ and $2.0 \%$ derived from balloon-borne in situ measurements (Van Haver et al. 1996; Beekmann et al. 1997).

The monthly distribution of the annual total of tropopause folds shows a maximum in November-February and a secondary maximum in July (Fig. 5). From the 183 tropopause folds observed over Wales, 73 (40\%) occurred in winter (December-February) and 31 (17\%) in summer (June-August). Previous studies have also shown that tropopause folds occur predominantly during winter; for example, the seasonal cycle observed by Sprenger et al. (2003) based on ECMWF analyses shows that deep folds occur most frequently in midlatitudes during the winter.

A clear correspondence was found between the occurrence of folds and the North Atlantic Oscillation (NAO) index (Fig. 6). The NAO is the dominant mode of large-scale atmospheric variability in the North Atlantic (Dickson et al. 2000), and its strength can be derived as an index that is traditionally defined as the normalized pressure difference between a station in the Azores (Portugal) and one in Iceland. Jones et al. (1997) have extended the NAO series to the early 1820s using data from Gibraltar and Reykjavik (Iceland), and their definition of the NAO index is used here. The Pearson correlation coefficient $r$ between the monthly NAO index and the monthly number of tropopause folds is 0.57 $(p<0.0001)$. During the positive phase of the NAO, the jet stream has a more zonal flow, and the storm track has a northeastward orientation taking depressions into northwest Europe. An example, corresponding to a peak in tropopause-fold occurrence, occurs in winter 2006-07 and in April-May 2009. Similarly, persistent negative NAO in 2010 coincided with a minimum in fold occurrence. However, the relationship does not always hold, as was the case during the first half of 2006. More work is required to understand why some seasons show a clear correspondence whereas others do not.

\section{Convective storms}

\section{a. Data acquisition and processing}

Convective storms were identified using data from the weather radar network operated by the Met Office, comprising $15 \mathrm{C}$-band (5-cm wavelength) radars. From 1997-2005, radar products were generated at 15-min intervals with $5-\mathrm{km}$ grid spacing by the Met Office's processing and nowcasting system (Golding 1998) after the quality control and corrections of the data were 


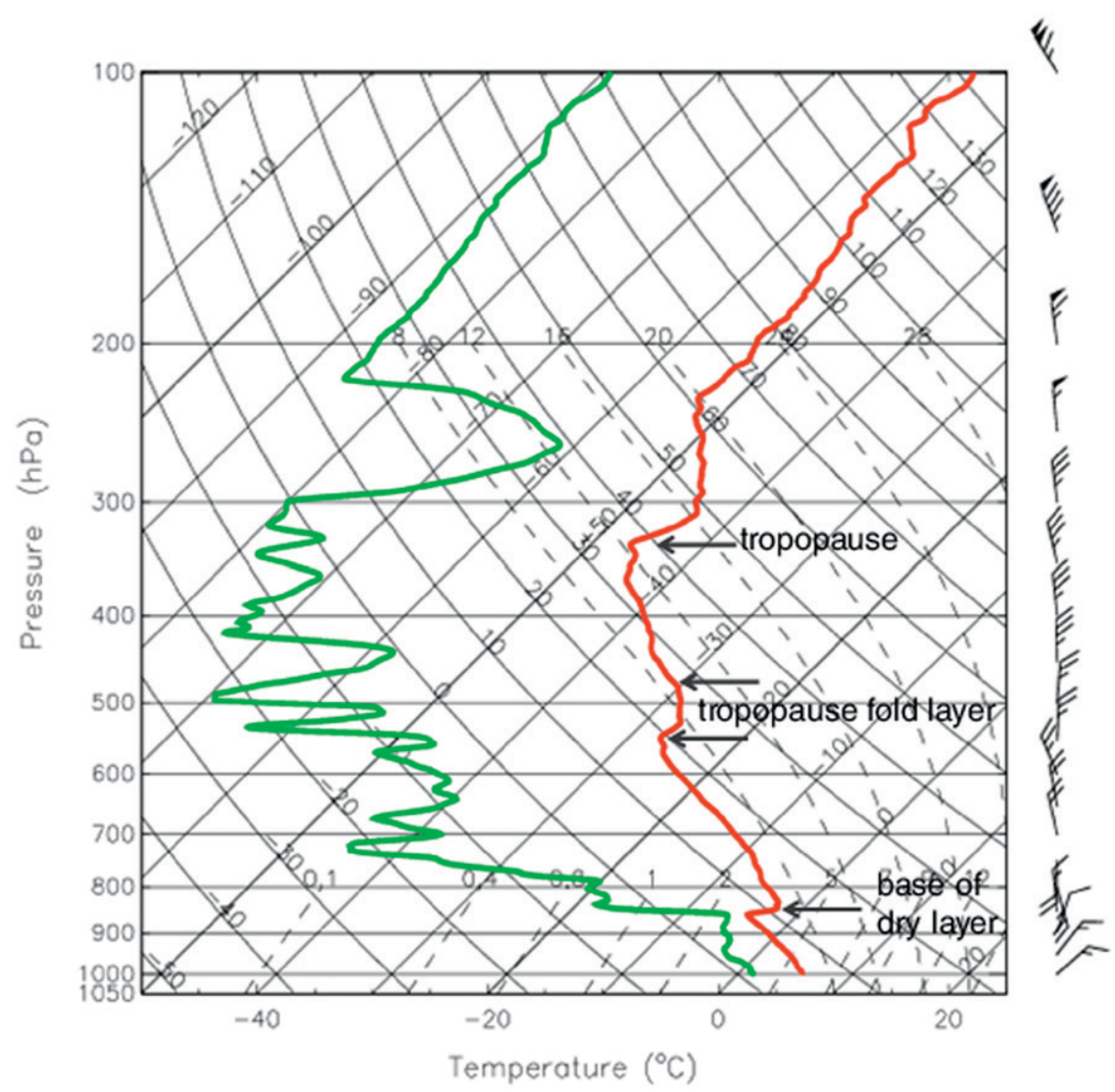

FIG. 4. Radiosonde observation at 0600 UTC 7 Nov 2010 at Castor Bay, 275 km northnorthwest from the MST radar. Wind speeds are in $\mathrm{m} \mathrm{s}^{-1}$ (one pennant, full barb, and half-barb denote 25,5 , and $2.5 \mathrm{~m} \mathrm{~s}^{-1}$, respectively).

carried out at radar sites. Radar products such as composite rain rate were mostly based on reflectivity measurements at a single elevation angle (Harrison et al. 2009).

The radar-data process chain was reengineered in recent years, and a new radar-data processing and product generation system was introduced in 2005 (Radarnet IV; Harrison et al. 2009). In the new product generation system, the radar data are resampled to a Cartesian grid after all the corrections are applied centrally to the highest resolution data in polar format. In this study, 1-km composite rain-rate data available every 5 min were used to detect and classify convective storms. The radar data for 2006-07 were obtained from the high-resolution $\left(1^{\circ} \times 600 \mathrm{~m}\right)$ reflectivity volume data out to a range of $255 \mathrm{~km}$ from the radar site. The composite rain-rate data were derived from radar data in Cartesian format from the individual radars. This processing method was further improved in 2008; thus, the composite rain-rate data for 2008-10 were generated directly from the composite data in polar format. Both processing methods improved the quality of the radar data, but the more recent method, described below, allows more detailed structure to the radar data. In this article, the use of both methods for deriving estimates of precipitation has no effect on the detection and classification of convective storms as described in sections $3 b$ and $3 \mathrm{c}$.

The first step in deriving estimates of precipitation rate from reflectivity data consists of several quality controls and corrections that include radar pointing errors (Darlington et al. 2003), clutter (Sugier et al. 2002), and beam blockage (Kitchen et al. 1994). A set of flags shows whether data in each cell are valid, noise, or invalid (cluttered and blocked data are invalid).

For the second step, the flags are used to identify the lowest elevation with valid data (i.e., uncluttered and unblocked). Third, a physically based scheme is applied in which an idealized vertical profile of reflectivity is defined for each pixel, based on cloud-top satellite measurements and numerical weather prediction model fields (wind, humidity, freezing level; Kitchen et al. 1994). This idealized profile incorporates parameterization of the bright band and orographic enhancement. 


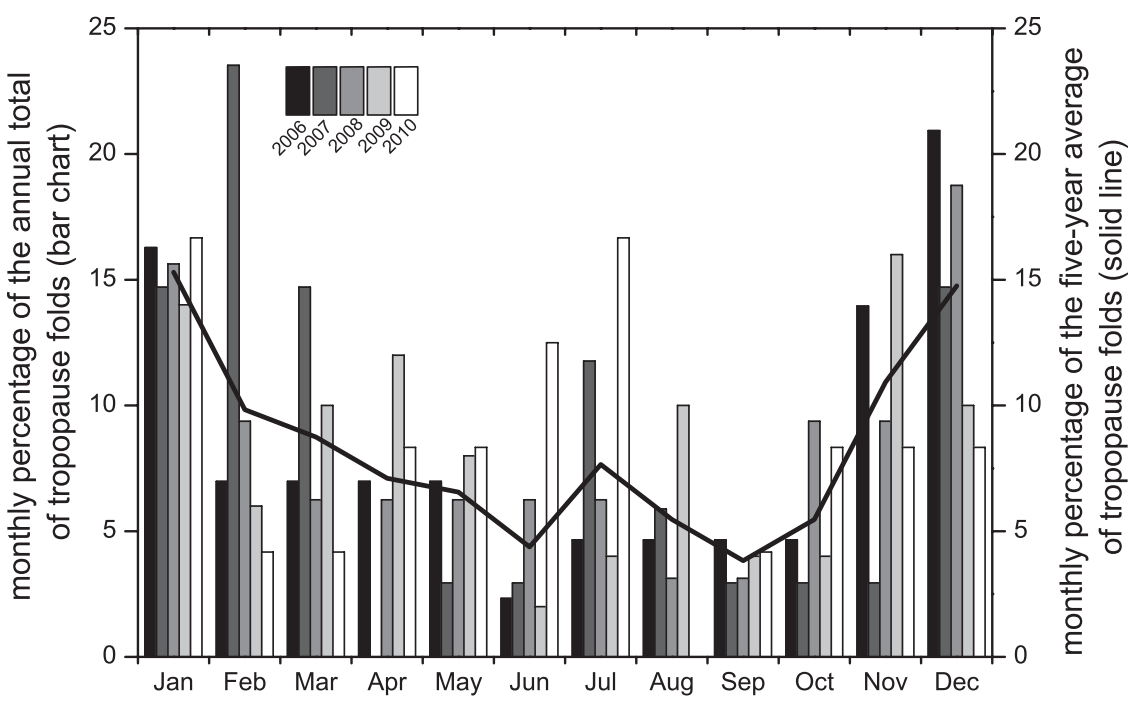

FIG. 5. Percentage of the annual total of tropopause folds occurring in each month for the years 2006-10 (bar chart), and the percentage of five-year average of tropopause folds (solid line).

The best-fit profile is then obtained through a series of iterations to minimize the differences between observed surface rainfall rates and those derived from the profile (Kitchen et al. 1994). The reflectivity is then converted to rain rate using a constant $Z-R$ relationship $(Z=$ $200 R^{1.6}$; Harrison et al. 2000). At this stage, the polar data are converted to Cartesian format using a distanceweighting method between the centroid of a polar cell and that of a Cartesian cell (Harrison et al. 2009). The final product, the U.K. composite rain rate, is derived by selecting data from the radar that has the scan with the lowest elevation angle with unflagged data (Harrison et al. 2009).

\section{b. Data and methods}

In this article, a storm is defined as an area greater than $10 \mathrm{~km} \times 10 \mathrm{~km}$ characterized by a precipitation rate greater than $2 \mathrm{~mm} \mathrm{~h}^{-1}$ (about $27 \mathrm{dBZ}$ ) with a maximum of at least $4 \mathrm{~mm} \mathrm{~h}^{-1}$ (about $33 \mathrm{dBZ}$ ) persisting for more than $30 \mathrm{~min}$ in the study domain (Fig. 1). Gallus et al. (2008) applied a similar technique to define convective storms occurring in a 10 -state region of the central United States. In their study, a convective storm was defined as an area of at least $6 \mathrm{~km} \times 6 \mathrm{~km}$ where the echo exceeded $10 \mathrm{~dB} Z$, with a maximum echo exceeding $30 \mathrm{~dB} Z$, persisting for at least $1 \mathrm{~h}$. The criteria in Gallus et al. (2008) were applied to radar images with $2-\mathrm{km}$ grid spacing, available every $30 \mathrm{~min}$. In previous studies, radar reflectivity of $28-36 \mathrm{dBZ}$ were used to define convective storm initiation (Wilson and Schreiber 1986; Mecikalski and Bedka 2006; Lima and Wilson 2008; Weckwerth et al. 2011); thus, the value of $33 \mathrm{~dB} Z$ used here is consistent with previous studies.

\section{c. Climatology}

The radar-based climatology of convective storms resulted in 685 cases, corresponding to an annual average of 137 cases. The monthly variation of the number of convective storms displays a broad maximum during May-January with a prominent minimum in February-April (Fig. 7). This broad maximum is unusual compared to locations in the central United States that have one maximum in storm occurrence each year during the warm season (e.g., Kelly et al. 1985; Doswell et al. 2005). To identify possible reasons for this difference, we examine the convective storm environments for two different locations throughout the year.

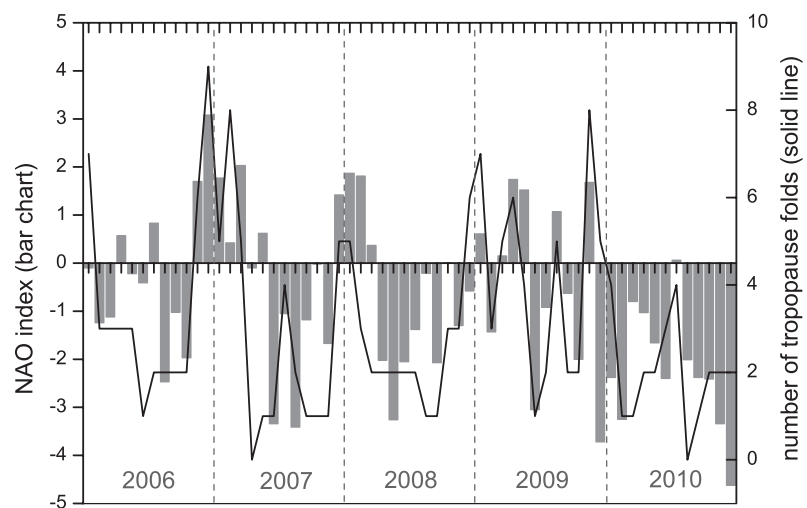

FIG. 6. Monthly number of tropopause folds (line) overlaid with the monthly North Atlantic Oscillation index (shaded) from January 2006 to December 2011. (The NAO index values were provided by the Climatic Research Unit, University of East Anglia, available online at http://www.cru.uea.ac.uk.) 


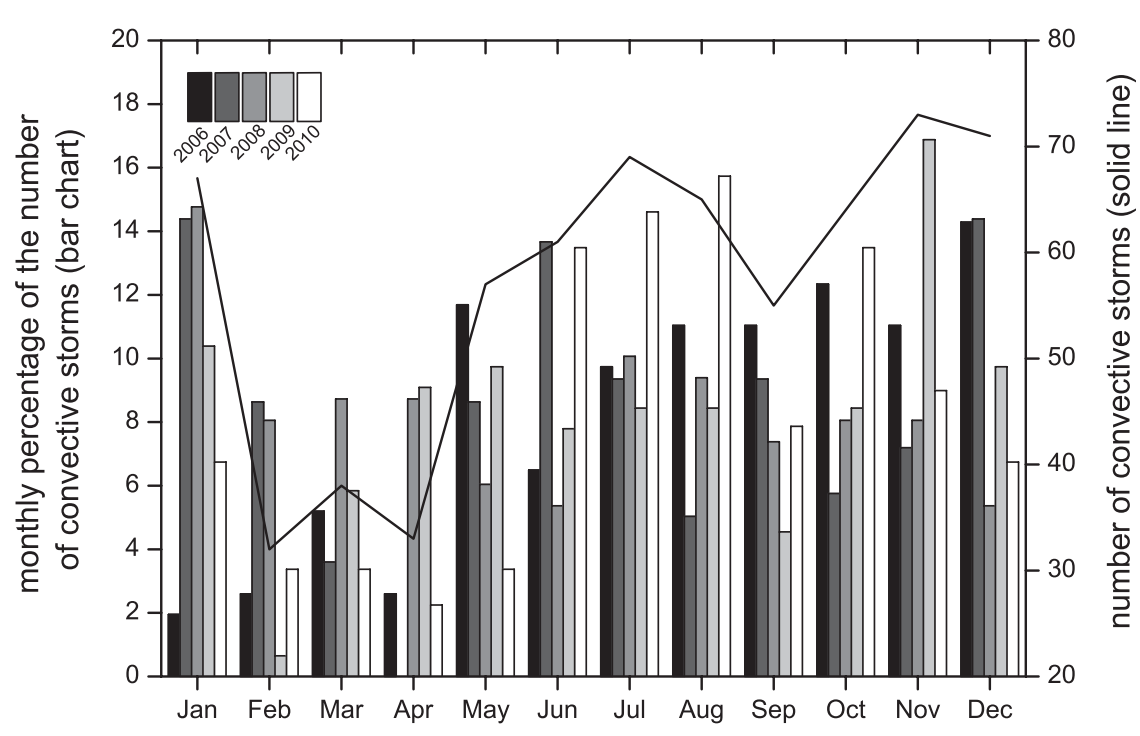

FIG. 7. Number of convective storms by month for each month in 2006-10 (solid line), and the percentage of the annual total occurring in each month, for each year (bar chart).

Following Brooks et al. (2007), annual cycles are constructed of mean mixing ratio over the lowest $100 \mathrm{hPa}$ and mean 700-500-hPa lapse rate. These two quantities represent two of the ingredients for deep moist convection. High-resolution (every $2 \mathrm{~s}$ ) radiosonde data for 2006-10 were used to construct the annual cycle for Aberporth (Fig. 8a), located $40 \mathrm{~km}$ southsouthwest of the MST radar (Fig. 1). The values when the mixing ratio was highest were selected for a particular day, and the mean for each day of the year (ignoring 29 February) was then calculated. To smooth the data, a 31-day running mean was computed.

The resulting mean annual cycle for Aberporth takes the form of a figure- 8 shape and can be divided into two main periods (Fig. 8a):

1) from early May to early October, high values of mean mixing ratio $\left(5.5-8.5 \mathrm{~g} \mathrm{~kg}^{-1}\right)$ occur with relatively low lapse rates $\left(5.8^{\circ}-6.1^{\circ} \mathrm{C} \mathrm{km}{ }^{-1}\right)$;

2) from early November to early April, the mean mixing ratios decrease from 5.0 to $4.0 \mathrm{~g} \mathrm{~kg}^{-1}$, and relatively high lapse rates $\left(6.1^{\circ}-6.6^{\circ} \mathrm{C} \mathrm{km}^{-1}\right)$ occur.

Rapid transitions between these two periods occur in October and April. A similar graph for Watnall (not shown), a radiosonde station situated $10 \mathrm{~km}$ northwest of Nottingham and $240 \mathrm{~km}$ northeast of Aberporth, shows an annual cycle similar to Fig. 8a, thus indicating that the sounding characteristics are not local to Wales and they represent a larger area.

For comparison to a location in the central United States, we use the data provided by H. Brooks (2012, personal communication) for the 1958-99 annual cycle derived from the National Centers for Environmental Prediction-National Center for Atmospheric Research (NCEP-NCAR) reanalysis dataset (Kalnay et al. 1996). For Oklahoma City, Oklahoma, relatively high mixing ratios and lapse rates (Fig. 8b) occur during the spring and summer months when convective storms are at their most intense. By comparison, at Aberporth, high lapse rates are associated with low mixing ratios and small lapse rates are associated with high mixing ratios (Fig. 8a). When overlaid on the Oklahoma City annual cycle (Fig. 8b), the cycle for Aberporth is generally much more stable with smaller low-level moisture content than Oklahoma City. Although these graphs provide insight into the annual cycle of stability and moisture, they do not appear to provide an explanation for why there is a minimum in convective storms in FebruaryApril, a time when the sounding characteristics are not substantially different from the more active period in November-January. The number of tropopause folds is lower during February-April than November-January (Fig. 5), suggesting one possible explanation. Further work is needed to understand the seasonal cycle of convective storms in the United Kingdom.

Storms were also classified based on the dominant morphology over their lifetime. The lifetime of the storm is defined as the first and last time when the storm exhibits a maximum rainfall rate greater than $4 \mathrm{~mm} \mathrm{~h}^{-1}$. A manual classification scheme was preferred to an automated one because the classification of convective storms can be somewhat arbitrary because of the existence of a continuum of convective storm morphologies, rather than discrete categories (Vasiloff et al. 1986). The 

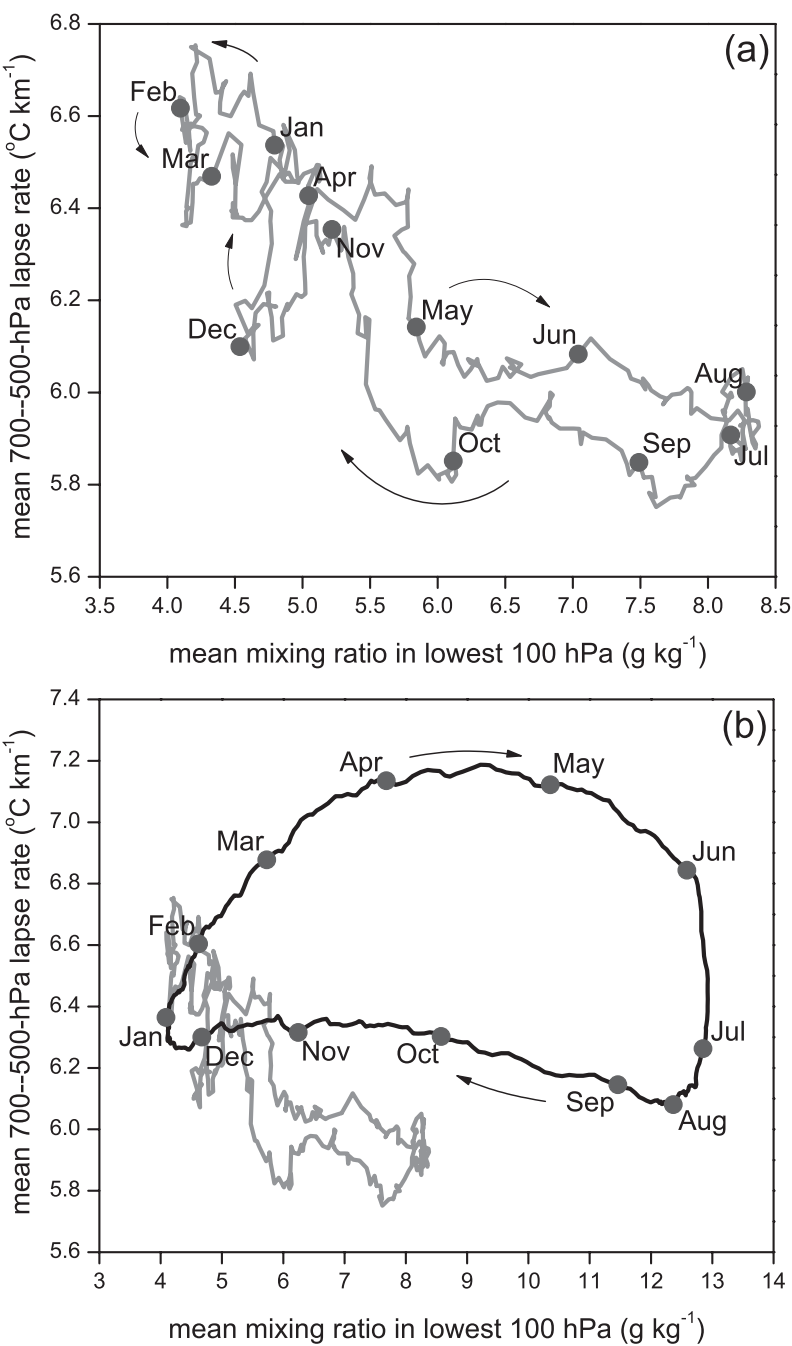

FIG. 8. Mean annual cycle of the lowest 100-hPa mixing ratio and 700-500-hPa lapse rate for (a) Aberporth for 2006-10, and (b) Oklahoma City for 1958-99 (black line) (courtesy of H. Brooks) and Aberporth for 2006-10 (gray line). The first days of each month are indicated by the labeled dots.

manual classification scheme was also preferred because of the relatively small volume of weather radar data to be analyzed.

Following Gallus et al. (2008), the storms were classified as isolated cells, multicellular lines, or nonlinear clusters (Fig. 9). Isolated cells (Fig. 9a) were defined as those storms in which the strongest radar echoes were organized into discrete, individual cells. Multicellular lines (Fig. 9b) were defined as storms for which the strongest radar echoes were organized and connected along a line. Nonlinear clusters (Fig. 9c) were defined as storms for which the strongest radar echoes were cellular, but not connected in a line.

Multicellular lines were most prevalent with 298 cases (43.5\% of all convective storms). Isolated cells were observed in 227 cases ( $33.1 \%$ of all convective storms), and nonlinear clusters in 160 cases $(23.4 \%$ of all convective storms). Multicellular lines were most common in late fall and early winter, with a peak in October (Fig. 10). Isolated cells were more frequent in MaySeptember with a peak in July. Nonlinear clusters were most common in November-January.

\section{Tropopause folds and convective storms}

In this section, we link the two datasets of tropopause folds and convective storms to examine how convective storms are modulated by tropopause folds. In this way, we aim to better understand how tropopause folds affect the location, intensity, and morphology of resulting convection.

\section{a. Data and method}

Figure 11 presents a schematic of a zonal cross section through an upper-level trough. Figure 2 is an example of a case occurring on the western half of this trough. On this schematic, four regions were defined: east of the trough, underneath the tropopause fold on the eastern side of the trough (eastern-side fold), underneath the trough, and underneath the fold on the western side of the trough (western-side fold). The region east of the trough, ahead of the eastern-side fold, was included in the analysis because this region is characterized by tropospheric ascent due to the advancing PV maximum (Hoskins et al. 1985). We define the time interval of a tropopause fold (eastern-side and western-side folds) as the period when all four criteria for tropopause fold identification described in section $2 \mathrm{a}$ are satisfied. We associate a convective storm (defined in section $3 b$ ) with a tropopause fold if the storm is observed during this time interval and is less than $100 \mathrm{~km}$ from the MST radar (Fig. 1). This search area was defined based on previous studies showing that tropopause folds have a length scale of 100-200 km (e.g., Keyser and Shapiro 1986; Elbern et al. 1998). The storms are then assigned to the eastern-side fold if the sloping layer of vertical wind shear from the MST radar is ascending with time, or to the western-side fold if the layer is descending. The convective storms from the region east of the trough are those observed east of the MST radar in a $200 \mathrm{~km} \times$ $200 \mathrm{~km}$ area (Fig. 1) when the eastern-side fold is observed by the MST radar for the first time. The convective storms are assigned to the region beneath the upperlevel trough if they are observed in a $200 \mathrm{~km} \times 200 \mathrm{~km}$ area east of the western-side fold when this fold is observed by the MST radar for the first time, or west of the eastern-side fold (Fig. 1) when the fold is observed for the last time. 


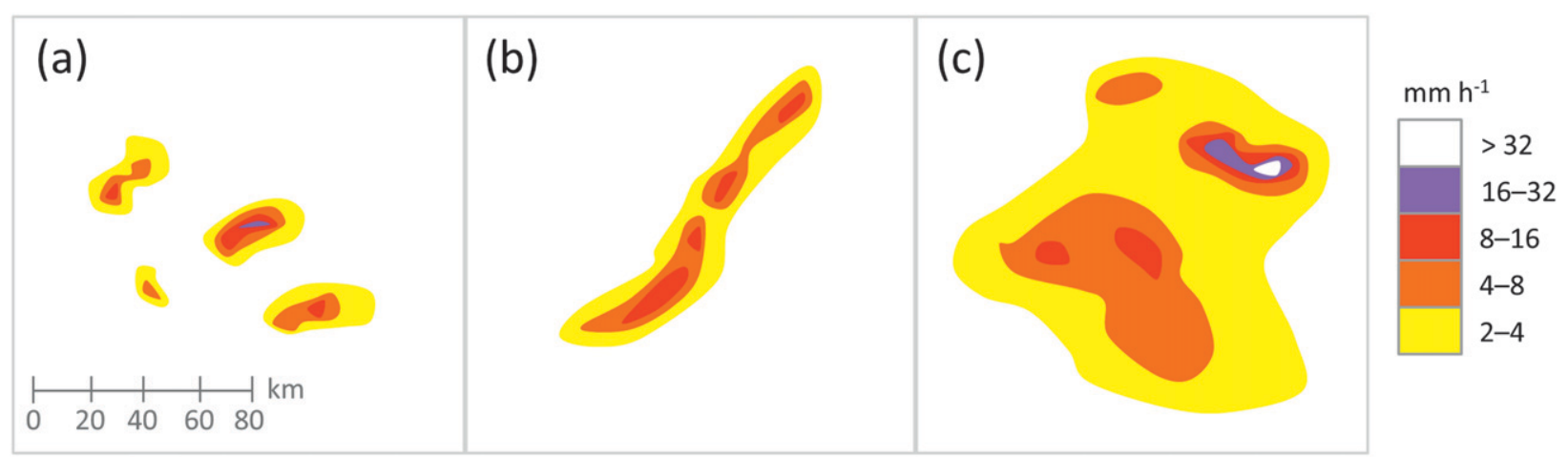

FIG. 9. Schematic representation of the storm classification scheme used in this study. The storms are classified based on the dominant storm morphology: (a) isolated cells, (b) multicellular lines, or (c) nonlinear clusters [adapted from Gallus et al. (2008)].

This classification scheme is reminiscent of that for upper-level frontogenesis proposed by Schultz and Doswell (1999). They showed that upper-level fronts could form in northwesterly flow (as had been typically described in the literature) or in southwesterly flow. Fronts forming in northwesterly flow tended to form in diffluence, whereas fronts forming in southwesterly flow tended to form in confluence (Schultz and Doswell 1999; Schultz and Sanders 2002; Schultz and Zhang 2007). Of the 183 tropopause folds in this study, $128(70 \%)$ occurred in northwesterly flow and $55(30 \%)$ occurred in southwesterly flow.

\section{b. Climatology}

From the 685 convective storms identified in this study, $155(22.6 \%)$ were associated with tropopause folds (Fig. 12a). The remaining 530 (77.4\%) have a monthly distribution with a maximum in June-August and a secondary maximum in October-December (Fig. 12a).

From the 183 tropopause folds identified in this study, $104(56.8 \%)$ were associated with convective storms (Fig. 12b). The tropopause folds associated with convective storms have a monthly distribution similar with that for the total number of tropopause folds, with a maximum in November-February and a secondary maximum in July (Fig. 12b). The monthly variation of the percentage from the total number of folds of the folds associated with convective storms displays a main maximum in December and a secondary one in September, with a minimum in March (Fig. 12b).

The distribution of the 104 tropopause folds associated with convective storms is shown in Fig. 13 as a function of the regions in Fig. 11. From the 55 easternside folds, $37(67.3 \%)$ were associated with convective storms. From this sample of 37, $23(62.2 \%)$ showed a preponderance of multicellular lines, representing the dominant morphology of convective storms associated with eastern-side folds, 11 (29.7\%) were mainly isolated cells, and $3(8.1 \%)$ were mainly nonlinear clusters. From the 128 western-side folds, $42(32.8 \%)$ were associated with convection. From this sample of 42,30 (71.4\%) showed a preponderance of isolated cells, representing the dominant morphology of convective storms associated with western-side folds, 7 (16.7\%) were mainly multicellular lines, and $5(11.9 \%)$ mainly nonlinear clusters. East of the upper-level trough, convective storms were observed in 28 of the 55 cases $(51 \%)$. Multicellular lines were observed in 27 of the 28 cases (96.4\%), and isolated cells in one case $(3.6 \%)$, indicating that linear organization is favored in this region of synoptic-scale ascent. Nonlinear clusters are much less prevalent in the dataset of convective storms associated with tropopause folds that in the general dataset (Fig. 10).

Underneath the upper-level trough, convective storms were observed in 48 of the 183 cases (26.2\%). Of these 48 cases, isolated cells dominated in 30 cases $(62.5 \%), 10$ cases $(20.8 \%)$ were mainly multicellular lines, and 8 $(16.7 \%)$ cases were mainly nonlinear clusters. When

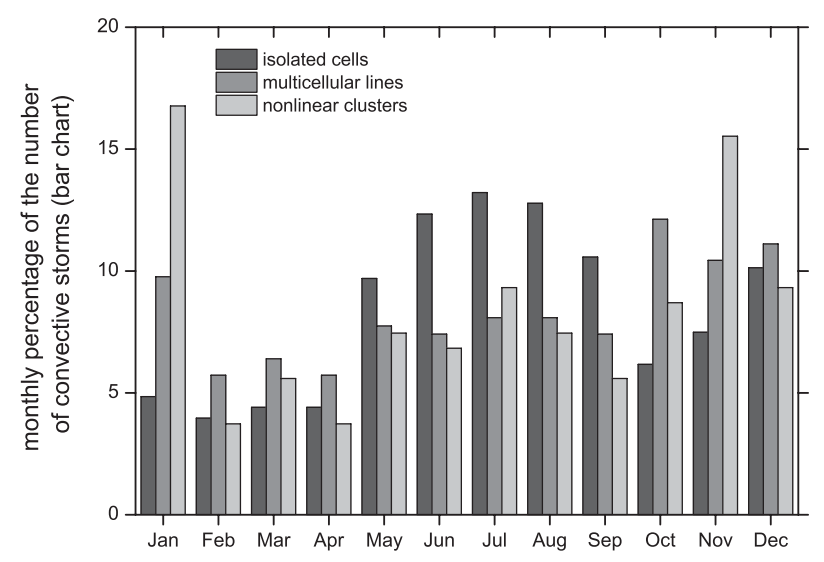

FIG. 10. Percentage of convective storms corresponding to each morphology (isolated cells, multicellular lines, nonlinear clusters) found in each month. 


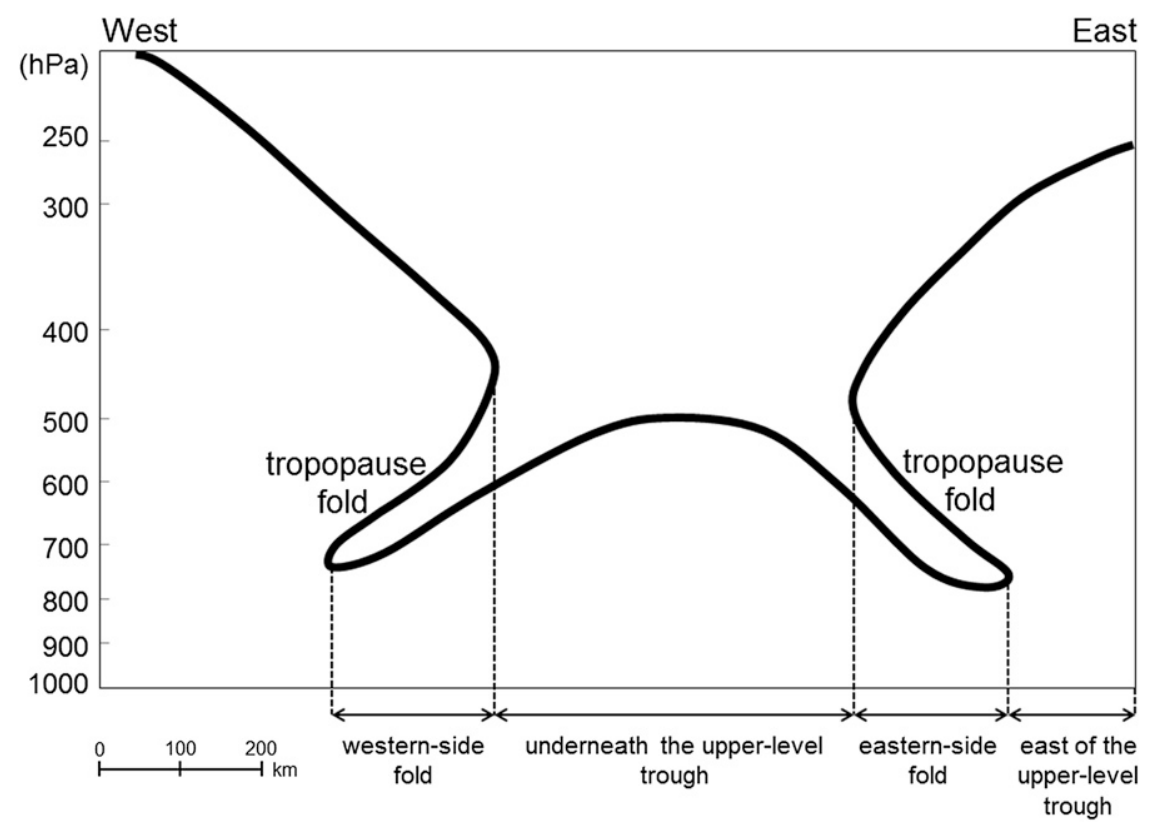

FIG. 11. Schematic representation of the height of the tropopause across an upper-level trough. Four regions were defined as east of the upper-level trough, underneath the tropopause fold on the eastern-side of the trough (eastern-side fold), underneath the upper-level trough, and underneath the tropopause fold on the western-side of the trough (western-side fold). Convective storms were associated with each of these regions in Fig. 13.

compared with the distribution of convective storms associated with eastern-side folds and assuming that all the ingredients for deep, moist convection are present in both regions, this result suggests that the presence of a tropopause fold is associated with a greater probability of observing convective storms. The distribution of convective storms underneath the upper-level trough is similar to the distribution for the western-side fold. Assuming that all the ingredients for deep, moist convection are present in both regions, the presence of a western-side fold is associated with a greater probability of observing isolated cells.

\section{Relationship with the synoptic-scale forcing}

Understanding the relationship between convective storms and the environment in which these storms evolve is mainly based on numerical modeling of idealized convective storms. Weisman and Klemp (1982) showed that the behavior of convective storms is influenced by local buoyancy and deep-layer $(0-6 \mathrm{~km})$ shear. They found that the bulk Richardson number (BRN; Moncrieff and Green 1972), which combines CAPE and deep-layer shear in one term, can be used to forecast the morphology of convective storms. Thus, BRN values between 15 and 45 were associated with supercells, whereas values greater than 45 were associated with multicell or ordinary cell convection. In real situations, however, substantial overlap between parameters (e.g., CAPE, 0-6-km shear, BRN) occurs for different storm morphologies. For example, data from Aberporth soundings from 2006 to 2010 with CAPE $>50 \mathrm{~J} \mathrm{~kg}^{-1}$ (not shown) indicated that there is overlap between the ranges of BRN values for different storm classifications. Other studies have shown substantial overlap as well (e.g., Rasmussen and Blanchard 1998; Elmore et al. 2002; Schumann and Roebber 2010). Thus, BRN alone is insufficient to determine the convective structure. We propose that the lack of synoptic forcing in the Weisman and Klemp (1982) simulations may explain why CAPE and shear alone are insufficient to determine the morphology of convective storms.

Indeed, Gold and Nielsen-Gammon (2008) showed that stronger PV anomalies are associated with $20 \%-$ $30 \%$ more CAPE, more ascent downshear of the PV anomaly, and less storm-relative environmental helicity (Davies-Jones et al. 1990). Thus, the stronger the PV anomaly, the greater the likelihood of widespread convection, and possibly less likelihood of tornadic convection (Gold and Nielsen-Gammon 2008). In a different study, Schumann and Roebber (2010) used a multiparameter discriminant analysis to show that multicellular convection (lines and clusters) is favored under strong synoptic forcing. These results provide more support for 

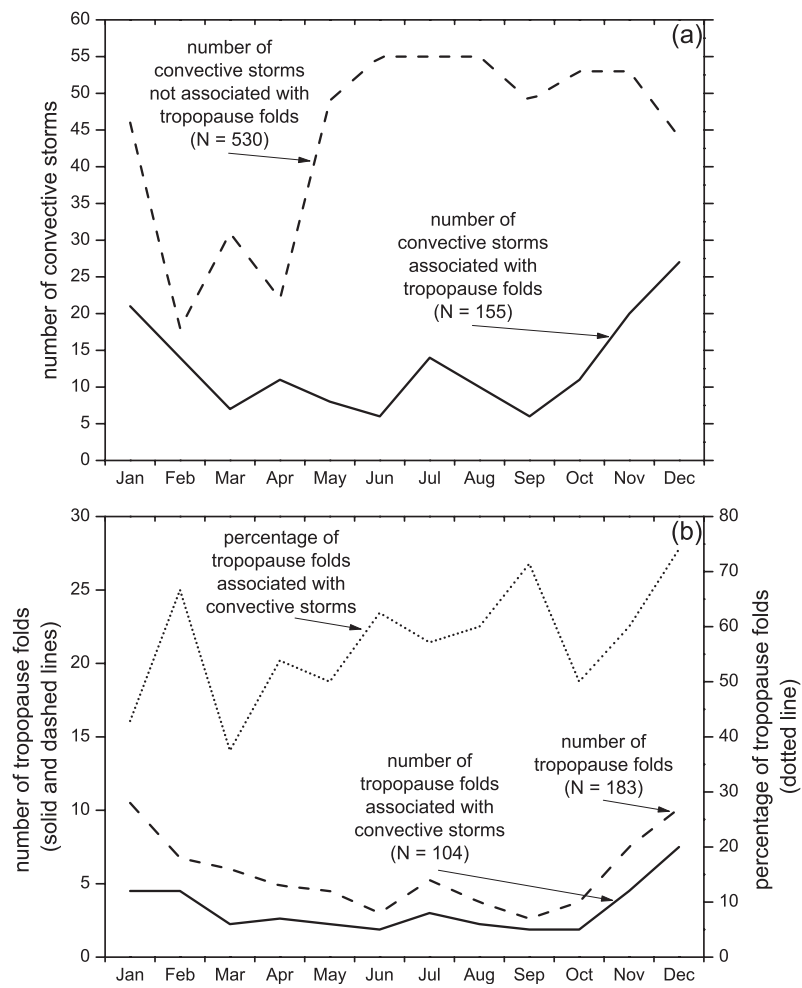

FIG. 12. (a) The number of convective storms associated with tropopause folds (solid line), and the number of convective storms not associated with tropopause folds (dashed line) occurring in each month for the years 2006-10. (b) Monthly variation of the number of tropopause folds (dashed line) and number of tropopause folds associated with convective storms (solid line) detected by month between 2006 and 2010. The dotted line represents the percentage from the total number of folds of the tropopause folds associated with convective storms.

the argument advanced by Roebber et al. (2002) that the increasing synoptic forcing during the evening in the 3 May 1999 tornado outbreak in Oklahoma and Kansas led to isolated supercellular convection becoming a linear mesoscale convective system. The results from the present study are consistent with the results of these previous studies because, on the east side of the trough where synoptic forcing for ascent tends to occur, the morphology of the convective storms is dominated by multicellular lines (Fig. 13). Thus, our study confirms the importance of synoptic-scale forcing for convectivestorm morphology.

\section{Conclusions}

This study focuses on the climatological characteristics of tropopause folds associated with convective storms over Wales, United Kingdom. Data from the MST radar from 2006 to 2010 were used to identify tropopause folds. Weather radar data from the Met
Office, for the same period were used to identify convective storms. The main conclusions are as follows:

1) The monthly distribution of the 183 tropopause-fold events over the MST radar shows a maximum in January and a secondary maximum in July in agreement with previous midlatitude climatologies.

2) A radar-based climatology of convective storms for Wales resulted in 685 cases. The monthly distribution of these cases displays two maxima in May-August and October-January and an abrupt minimum in February-April.

3) The annual cycle of low-level moisture and 700 500-hPa lapse rate at Aberporth is distinctly different from the same annual cycle for Oklahoma City in the central United States. Although the highest mixing ratios in Aberporth and Oklahoma City both occur in the summer, the highest lapse rates occur in January and February in Aberporth versus April and May in Oklahoma City.

4) Following the approach by Gallus et al. (2008), the convective storms were classified based on their dominant morphology as isolated cells, multicellular lines, or nonlinear clusters. Multicellular lines were the most common (43.5\%) type of convective storms, with a monthly distribution that peaks in October. Isolated cells $(33.1 \%)$ were most common in MaySeptember, and nonlinear clusters $(23.4 \%)$ were most common in November-January.

5) Tropopause folds were associated with convective storms in 104 cases, representing 56.8\% of the tropopause folds identified in this study. The monthly distribution of these cases reveals a seasonal cycle with a maximum in December.

6) From the 55 eastern-side folds, $67.3 \%$ were associated with convective storms. The convective mode in this region was dominated by multicellular lines. For the 128 tropopause folds observed on the western side of an upper-level trough, $32.8 \%$ were associated with a convective storm. In this region, the convective mode was dominated by isolated cells. East of the upper-level trough, almost all convective storms were multicellular lines. These results lend support to the hypothesis that strong synoptic forcing is associated with more organized convective storms.

The aim of this research is to provide the basis for understanding how deep convection is modulated by tropopause folds in order to improve the forecasting of convective storms. Although this article is focused on the climatological aspects of tropopause folds and convective storms over Wales, some of the conclusions confirm previous results obtained in the United States, thus showing the generality of these conclusions. 


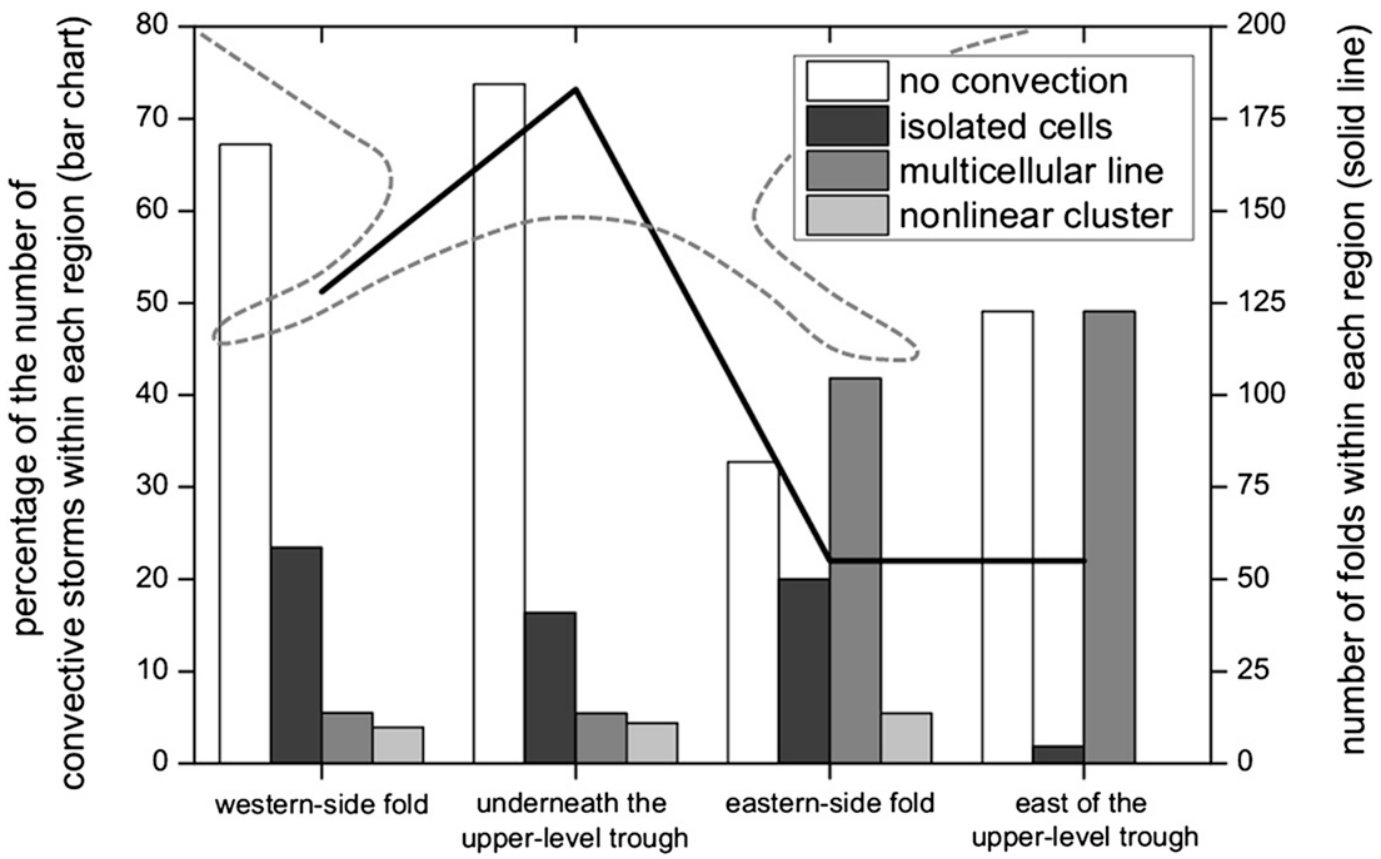

FIG. 13. The solid line shows the number of tropopause folds found in the four categories of Fig. 11. The dashed line reproduces the schematic tropopause location from that figure. The bar charts show the percentage occurrence of the different storm morphologies for each of the four categories.

Acknowledgments. We thank the Natural Environment Research Council (NERC) mesosphere-stratospheretroposphere radar facility for providing MST radar data for this study, and the Met Office for the weather radar data. Both datasets were supplied by the British Atmospheric Data Center (BADC). The NAO index values are provided by the Climatic Research Unit, University of East Anglia, Norwich, available online at http://www.cru. uea.ac.uk. Thanks to Harold Brooks for providing the dataset used in section 3c. The work was supported by NERC as part of the Tropopause Folding, Stratospheric Intrusions and Deep Convection (TROSIAD) project, Grant NE/H008225/1.

\section{REFERENCES}

Beekmann, M., and Coauthors, 1997: Regional and global tropopause fold occurrence and related ozone flux across the tropopause. J. Atmos. Chem., 28, 29-44.

Brooks, H. E., A. R. Anderson, K. Riemann, I. Ebbers, and H. Flachs, 2007: Climatological aspects of convective parameters from the NCAR/NCEP reanalysis. Atmos. Res., 83, 294-305.

Browning, K. A., and R. Reynolds, 1994: Diagnostic study of a narrow cold-frontal rainband and severe winds associated with a stratospheric intrusion. Quart. J. Roy. Meteor. Soc., 120, 235-257.

_ , and N. M. Roberts, 1994: Use of satellite imagery to diagnose events leading to frontal thunderstorms: Part I of a case study. Meteor. Appl., 4, 303-310.
Danielsen, E. F., 1968: Stratospheric-tropospheric exchange based on radioactivity, ozone, and potential vorticity. J. Atmos. Sci., 25, 502-518.

Darlington, T., M. Kitchen, J. Sugier, and J. de Rohan-Truba, 2003: Automated real-time monitoring of radar sensitivity and antenna pointing accuracy. Preprints, 31st Conf. on Radar Meteorology, Seattle, WA, Amer. Meteor. Soc., 538-541.

Davies-Jones, R., D. Burgess, and M. Foster, 1990: Test of helicity as a tornado forecast parameter. Preprints, 16th Conf. on Severe Local Storms, Kananaskis Park, AB, Canada, Amer. Meteor. Soc., 588-592.

Dickson, R. R., and Coauthors, 2000: The Arctic Ocean response to the North Atlantic Oscillation. J. Climate, 13, 2671-2696.

Doswell, C. A., III, and L. F. Bosart, 2001: Extratropical synopticscale processes and severe convection. Severe Convective Storms, C. A. Doswell, III, Ed., Amer. Meteor. Soc., 27-70.

$\longrightarrow$, H. E. Brooks, and M. P. Kay, 2005: Climatological estimates of daily local nontornadic severe thunderstorm probability for the United States. Wea. Forecasting, 20, 577-595.

Elbern, H., J. Hendricks, and A. Ebel, 1998: A climatology of tropopause folds by global analyses. Theor. Appl. Climatol., 59, 181-200.

Elmore, K. L., D. J. Stensrud, and K. C. Crawford, 2002: Ensemble cloud model applications to forecasting thunderstorms. J. Appl. Meteor., 41, 363-383.

Gallus, W. A., Jr., N. A. Snook, and E. V. Johnson, 2008: Spring and summer severe weather reports over the Midwest as a function of convective mode: A preliminary study. Wea. Forecasting, 23, 101-113.

Glickman, T. S., Ed., 2000: Glossary of Meteorology. 2nd ed. Amer. Meteor. Soc., $855 \mathrm{pp}$ 
Goering, M. A., W. A. Gallus Jr., M. A. Olsen, and J. L. Stanford, 2001: Role of stratospheric air in a severe weather event: Analysis of potential vorticity and total ozone. J. Geophys. Res., 106 (D11), 11 813-11 823.

Gold, D. A., and J. W. Nielsen-Gammon, 2008: Potential vorticity diagnosis of the severe convective regime. Part III: The Hesston tornado outbreak. Mon. Wea. Rev., 136, 1593-1611.

Golding, B. W., 1998: Nimrod: A system for generating automated very short range forecasts. Meteor. Appl., 5, 1-16.

Griffiths, M., A. J. Thorpe, and K. A. Browning, 2000: Convective destabilization by a tropopause fold diagnosed using potentialvorticity inversion. Quart. J. Roy. Meteor. Soc., 126, 125-144.

Harrison, D. L., S. J. Driscoll, and M. Kitchen, 2000: Improving precipitation estimates from weather radar using quality control and correction techniques. Meteor. Appl., 7, 135-144.

— cipitation estimates for hydrological uses. Proc. ICE Water Manage., 162, 125-135.

Hooper, D. A., and J. Arvelius, 2000: Monitoring of the Arctic winter tropopause: A comparison of radiosonde, ozonesonde and MST radar observations. Proc. MST9-COST76, Toulouse, France, SCOSTEP, Météo-France, COST, 385-388.

Hoskins, B. J., I. Drăghici, and H. C. Davies, 1978: A new look at the $\omega$-equation. Quart. J. Roy. Meteor. Soc., 104, 31-38.

- M. E. McIntyre, and A. W. Robertson, 1985: On the use and significance of isentropic potential vorticity maps. Quart. J. Roy. Meteor. Soc., 111, 877-946.

Johns, R. H., and C. A. Doswell III, 1992: Severe local storms forecasting. Wea. Forecasting, 7, 588-612.

Jones, P. D., T. Jonsson, and D. Wheeler, 1997: Extension to the North Atlantic Oscillation using early instrumental pressure observations from Gibraltar and south-west Iceland. Int. J. Climatol., 17, 1433-1450.

Kalnay, E., and Coauthors, 1996: The NCEP/NCAR 40-Year Reanalysis Project. Bull. Amer. Meteor. Soc., 77, 437-471.

Kelly, D. L., J. T. Schaefer, and C. A. Doswell III, 1985: Climatology of nontornadic severe thunderstorm events in the United States. Mon. Wea. Rev., 113, 1997-2014.

Keyser, D., and M. A. Shapiro, 1986: A review of the structure and dynamics of upper-level frontal zones. Mon. Wea. Rev., 114, 452-499.

Kitchen, M., R. Brown, and A. G. Davies, 1994: Real-time correction of weather radar data for the effects of bright band, range and orographic growth in widespread precipitation. Quart. J. Roy. Meteor. Soc., 120, 1231-1254.

Lawson, J., G. Vaughan, and D. M. Schultz, 2011: Classifying fronts in data from a VHF wind-profiling radar. Atmos. Sci. Lett., 12, 375-380.

Lima, M. A., and J. W. Wilson, 2008: Convective storm initiation in a moist tropical environment. Mon. Wea. Rev., 136, 1847-1864.

Markowski, P., and Y. Richardson, 2010: Mesoscale Meteorology in Midlatitudes. Wiley-Blackwell, $430 \mathrm{pp}$.

Mecikalski, J. R., and K. M. Bedka, 2006: Forecasting convective initiation by monitoring the evolution of moving cumulus in daytime GOES imagery. Mon. Wea. Rev., 134, 49-78.

Moncrieff, M. W., and J. S. A. Green, 1972: The propagation and transfer properties of steady convective overturning in shear. Quart. J. Roy. Meteor. Soc., 98, 336-352.

Nastrom, G., J. Green, K. Gage, and M. R. Peterson, 1989: Tropopause folding and the variability of the tropopause height as seen by the Flatland VHF radar. J. Appl. Meteor., 28, 1271-1281.

Newton, C. W., 1954: Frontogenesis and frontolysis as a threedimensional process. J. Meteor., 11, 449-461.
Parton, G., A. Dore, and G. Vaughan, 2010: A climatology of midtropospheric mesoscale strong wind events as observed by the MST radar, Aberystwyth. Meteor. Appl., 17, 340-354.

Pauley, P. M., N. L. Baker, and E. H. Barker, 1996: An observational study of the "Interstate 5" dust storm case. Bull. Amer. Meteor. Soc., 77, 693-720.

Rao, T. N., J. Arvelius, and S. Kirkwood, 2008: Climatology of tropopause folds over a European Arctic station (Esrange). J. Geophys. Res., 113, D00B03, doi:10.1029/2007JD009638.

Rasmussen, E. N., and D. O. Blanchard, 1998: A baseline climatology of sounding-derived supercell and tornado forecast parameters. Wea. Forecasting, 13, 1148-1164.

Reed, R. J., 1955: A study of a characteristic type of upper-level frontogenesis. J. Meteor., 12, 226-237.

— , and F. Sanders, 1953: An investigation of the development of a mid-tropospheric frontal zone and its associated vorticity field. J. Meteor., 10, 338-349.

Reid, H. J., and G. Vaughan, 2004: Convective mixing in a tropopause fold. Quart. J. Roy. Meteor. Soc., 130, 1195-1212.

Roberts, N. M., 2000: The relationship between water vapour imagery and thunderstorms. Internal Rep. 110, Joint Centre for Mesoscale Meteorology, Meteorological Office, $19 \mathrm{pp}$.

Roebber, P. J., D. M. Schultz, and R. Romero, 2002: Synoptic regulation of the 3 May 1999 tornado outbreak. Wea. Forecasting, 17, 399-429.

Schultz, D. M., and C. A. Doswell III, 1999: Conceptual models of upper-level frontogenesis in southwesterly and northwesterly flow. Quart. J. Roy. Meteor. Soc., 125, 2535-2562.

_ with the birth of mobile troughs in northwesterly flow. Mon. Wea. Rev., 130, 2593-2610.

_, and F. Zhang, 2007: Baroclinic development within zonally varying flows. Quart. J. Roy. Meteor. Soc., 133, 1101-1112.

Schumann, M. R., and P. J. Roebber, 2010: The influence of uppertropospheric potential vorticity on convective morphology. Mon. Wea. Rev., 138, 463-474.

Sprenger, M., M. Croci-Maspoli, and H. Wernli, 2003: Tropopause folds and cross-tropopause exchange: A global investigation based upon ECMWF analyses for the time period March 2000 to February 2001. J. Geophys. Res., 108, 8518, doi:10.1029/ 2002JD002587.

Sugier, J., J. Parent du Châtelet, P. Roquain, and A. Smith, 2002: Detection and removal of clutter and anaprop in radar data using a statistical scheme based on echo fluctuation. Proc. Second European Conf. on Radar in Meteorology and Hydrology, Delft, Netherlands, Copernicus GmbH, 17-24.

Thorpe, A. J., 1997: Attribution and its application to the mesoscale structure associated with tropopause folds. Quart. J. Roy Meteor. Soc., 123, 2377-2399.

Uccellini, L. W., 1990: Processes contributing to the rapid development of extratropical cyclones. Extratropical Cyclones: The Eric Palmén Memorial Volume, C. W. Newton and E. O. Holopainen, Eds., Amer. Meteor. Soc., 81-105.

— D. Keyser, K. F. Brill, and C. H. Wash, 1985: The Presidents' Day cyclone of 18-19 February 1979: Influence of upstream trough amplification and associated tropopause folding on rapid cyclogenesis. Mon. Wea. Rev., 113, 962-988.

Van Haver, P., D. De Muer, M. Beekmann, and C. Mancier, 1996: Climatology of tropopause folds at midlatitudes. Geophys. Res. Lett., 23, 1033-1036.

Vasiloff, S. V., E. A. Brandis, R. P. Davies-Jones, and P. S. Ray, 1986: An investigation of the transition from multicells to supercell storms. J. Climate Appl. Meteor., 25, 1022-1036. 
Vaughan, G., 2002: The UK MST radar. Weather, 57, 69-73.

— , and R. M. Worthington, 2000: Break-up of a stratospheric streamer observed by MST radar. Quart. J. Roy. Meteor. Soc., 126, 1751-1769.

_ J. D. Price, and A. Howells, 1994: Transport into the troposphere in a tropopause fold. Quart. J. Roy. Meteor. Soc., 120, 1085-1103.

Weckwerth, T. M., J. W. Wilson, M. Hagen, T. J. Emerson, J. O. Pinto, D. L. Rife, and L. Grebe, 2011: Radar climatology of the COPS region. Quart. J. Roy. Meteor. Soc., 137, 31-41.
Weisman, M. L., and J. B. Klemp, 1982: The dependence of numerically simulated convective storms on vertical wind shear and buoyancy. Mon. Wea. Rev., 110, 504-520.

Wernli, H., S. Dirren, M. A. Liniger, and M. Zillig, 2002: Dynamical aspects of the life cycle of the winter storm 'Lothar' (14-26 December 1999). Quart. J. Roy. Meteor. Soc., 128, 405-427.

Wilson, J. W., and W. E. Schreiber, 1986: Initiation of convective storms at radar-observed boundary-layer convergence lines. Mon. Wea. Rev., 114, 2516-2536. 